December 2019

\title{
Her Story: Accidental Library Instruction
}

Michelle Leasure

Valdosta State University, c.michelle.leasure@gmail.com

Follow this and additional works at: https://scholarworks.sjsu.edu/ischoolsrj

Part of the Information Literacy Commons

\section{Acknowledgements}

Thanks to Dr. Linda Most and Dr. Nicole Alemanne for their guidance and help in the researching and writing of this paper, and thanks to all of the LIS professors at Valdosta State University for all they have taught me.

\section{Recommended Citation}

Leasure, M. (2019). Her Story: Accidental Library Instruction. School of Information Student Research Journal, 9(2). https://doi.org/10.31979/2575-2499.090206 Retrieved from https://scholarworks.sjsu.edu/ ischoolsrj/vol9/iss $2 / 6$

This article is brought to you by the open access Journals at SJSU ScholarWorks. It has been accepted for inclusion in School of Information Student Research Journal by an authorized administrator of SJSU ScholarWorks. For more information, please contact scholarworks@sjsu.edu. 


\title{
Her Story: Accidental Library Instruction
}

\begin{abstract}
Game-based learning is a relatively new pedagogical method that typically targets students of the current and upcoming generations. Librarians have gradually begun experimenting with gamifying elements of library and research skills instruction to varying degrees of success. While some case studies and theoretical analyses are available currently, more published data will be necessary to evaluate and direct the development of game-based library instruction in the coming years. This paper explores attempts to use game-based learning techniques in library instruction courses and sessions, specifically highlighting Project Velius (developed by the University of Alabama Libraries) and its similarities to the commercially successful game Her Story, which was created for purely entertainment purposes but manages to present as an effective library instruction tool nonetheless. This examination suggests that academic libraries may be more capable in this arena than commonly believed, and the author ultimately recommends that academic libraries further embrace this pedagogical trend.
\end{abstract}

\section{Keywords}

Library Instruction, Game-Based Learning, Gamification, Education, Games, Academic Libraries

\section{Acknowledgements}

Thanks to Dr. Linda Most and Dr. Nicole Alemanne for their guidance and help in the researching and writing of this paper, and thanks to all of the LIS professors at Valdosta State University for all they have taught me.

\section{About Author}

Cayla Michelle Leasure is a student at Valdosta State University, pursuing her Master of Library and Information Science degree. She currently works as a Library Associate for the University of North Georgia Libraries, Oconee Campus. 


\section{Her Story: Accidental Library Instruction}

Her Story is an Indie (developed independently rather than through a large production company, in this case by Sam Barlow) video game that was released in 2015. The core of the game is a fictional police database containing clips of archived video footage of interviews from a cold case. The player assumes the role of detective, hunting down the clips and attempting to piece together the story to solve the case. It was nominated for and won several awards, including Game of the Year (Barlow, 2014a).

For the purposes of this paper, however, the most interesting aspect of $\mathrm{Her}$ Story is the core gameplay mechanic. The entire game takes place within the fictional police department database, and all the player can do is search the database for video files and play said files when they find them. This fictional database functions like most real databases, using keyword searches and Boolean operators to return results appropriate for the query. At the start of the game, the player has only the name of the woman being interviewed and the vague idea that this is a "missing person" case; everything else must be gleaned from found video clips and then plugged back into the database to unearth more results (Barlow, 2015). In short, the player is researching this narrative and discovering new avenues to investigate as they go, much as an academic scholar would research any other topic.

Without intending to, Barlow created a highly successful, narrative-driven, completely immersive library instruction tool. While the game alone obviously fails to cover the entire content of a full library instruction course or session, it does have the advantages of engaging players (learners) on its own merits and encouraging organic discovery-based learning. Traditional library instruction techniques unfortunately tend to lack these qualities, leading to a disconnect between the current pedagogy and current and future generations of library users and students. Librarians have not been blind to the development of game-based learning as a new pedagogy and have experimented with incorporating games into one-shot sessions and introductory activities, but they seem to have mostly limited themselves to these smaller efforts rather than fully embracing and investing in larger projects. One notable exception is the University of Alabama Libraries' Project Velius, which will be compared to Her Story in terms of scope, intention, and effectiveness in order to examine the potential gains if libraries were to more fully invest in game-based learning. Librarians cannot afford to hesitate any longer at this juncture between traditional pedagogy and newer, game-based methods; in order to remain relevant and reach current and future library users effectively, librarians should draw inspiration from fully-realized projects like Her Story in order to develop and implement their own immersive, organic library instruction tools.

\section{Teaching Information Literacy and Research Skills Today}

Library instruction is a key component in most academic librarians' job descriptions, and it tends to consume a significant portion of their working time. After all, the primary purpose of most academic libraries is to serve the students and faculty in their research pursuits. Additionally, there is a well-documented 
correlation between students' understanding and use of library resources, higher graduation rates, and higher GPAs upon graduation (Omeluzor, Akibu, Dika, \& Ukangwa, 2017, pp. 7-9). Furthermore, many academic libraries rely on student and faculty usage statistics and success rates to justify and secure funding, so ensuring that the academic community is both aware of library resource offerings and is comfortable using them has become very important.

Unfortunately, recent studies and anecdotal reflections both suggest that students' motivation and engagement with library instruction is declining. Buckley, E. Doyle and S. Doyle (2016) have connected this disturbing trend, along with similar statistics demonstrating a decline in class attendance, difficulties prompting engaging discussions in class, and even a rise in plagiarism and cheating incidents, with a disconnect between traditional pedagogical methods and the upcoming generation of students. "Generation Z" students seem to prefer highly social, fast-paced, technology-infused learning environments (Buckley et al., 2016, pp. 1-3). This conclusion has been borne out of several similar studies from around the world, including Zhang, Robb, Eyerman, and Goodman's (2017) examination of international students in higher education, as well as Omeluzor, Akibu, Dika, and Ukangwa's (2017) study of modern academic library instruction in Africa. In fact, in the latter study, their primary concluding recommendation was for librarians to adopt more modern methods of delivering content by using information and communication technologies (ICT) more frequently.

The fact that modern students are largely "digital natives" has a profound impact on how they learn and how they approach problems or tasks generally; it also seems to be creating a significant psychological roadblock to engagement with library instruction. A common thread across studies of modern library instruction students has been that they seem to believe they already know how to use the internet to gather research effectively (Buckley et al., 2016, pp. 3-4). Most of them have been using Google since they first discovered the internet, so they feel library instruction is something they simply do not need. It is not uncommon for this misconception to bleed over into faculty perceptions of library instruction, or even to the perceptions of the librarians themselves. In Fundamentals of Library Instruction, McAdoo (2012) notes that "just because a student has some proficiency with a computer does not necessarily mean he can use those skills to locate and retrieve relevant information" (p. 100). There is a world of difference between aptly Googling simple questions and efficiently combing through scholarly literature to find relevant research. The question is how to keep modern students engaged enough to learn the more specialized skills that library instruction can offer.

\section{Game-Based Learning}

Gamification is simply the application of game elements to other non-game aspects of life, and it is rapidly becoming a popular buzzword in many industries. Corporations in the retail and entertainment industries have been using gamified elements to drive sales and increase loyalty among customers for decades, and 
educators have increasingly begun incorporating gamification strategies to keep students engaged and increase student understanding of instructional content.

Because game-based learning is still very much a developing pedagogical method, some of the vocabulary can be confusing. "Game-based learning" is an umbrella term for two different pedagogical methods: gamification and "Serious Games" instruction (Kaneko, Saito, Nohara, Kudo, \& Yamada, 2018, p. 570). Serious Games instruction is having a learner play a game through which they acquire the full curriculum or content; the entire learning experience is contained within the game in these scenarios. Because this is a radically different approach to education, experiments using this technique are few and far between and tend to be limited to online or distance learning environments. Gamification is the far more immediately attainable and broadly applicable method, wherein some game elements are incorporated into an otherwise traditional learning environment. These game elements could be as general as teamwork and/or competition, or they could be as specific as leveling-up systems, point accrual with rewards, and/or rank and achievement systems. (Kaneko et al., 2018, pp. 570-571).

There are numerous benefits to gamifying learning experiences, as outlined by Gee (2007) in What Video Games Have to Teach Us About Learning and Literacy. For each individual learner, games offer the chance to learn by doing, encouraging experimentation and active, discovery-based learning. Numerous studies have proven that this sort of active, participatory learning often leads to more lasting knowledge and greater understanding than traditional lecture-style teaching. Additionally, games with teamwork elements foster a learning community, allowing students to build support networks with their peers that they can turn to if they encounter a difficult concept or problem. Games with intense competitive elements can draw in competitively-motivated students, encouraging them to further apply themselves in order to get ahead (Gee, 2007). These benefits may be amplified for distance/online learners in particular, as they often struggle with self-motivation and self-regulation as far as assignments and deadlines are concerned. The built-in scaffolding inherent to a multi-level game allows for big projects to be broken up into smaller tasks with more manageable deadlines, and if the game is enjoyable, motivation and willingness to participate can be expected to increase (Kaufmann, 2018, p. 129). Distance learners also often report a sense of isolation from their fellow students and the greater academic community, which can be remedied to some extent by social elements within games. Most games also incorporate and facilitate quick feedback loops, which can encourage communication with and familiarity with instructors (Kaufmann, 2018, p. 130).

In addition to the benefits provided for students, gamification also lends itself to great assessment opportunities for librarians, beyond the typical postexperience quizzes and self-reporting. Due to the nature of multi-level games, students typically will have to demonstrate mastery of the current content in order to earn points or move forward to the next level, so progression through the game can serve as an assessment marker in and of itself (Smale, 2011, p. 39). General competencies like critical thinking and inquiry skills are usually difficult to accurately measure, but can often be evaluated by observing gameplay 
interactions. This sort of "stealth assessment" has the additional benefit of not being obvious to students, which often produces more accurate data than selfreported responses or response collections in which the students are aware they are being tested (Kaya, 2010).

Even given these many positives associated with game-based learning, there are some negatives as well. Funding is almost always a concern for libraries of all types and developing gamified elements and/or full library instruction games (physical or especially digital) can be very expensive. As L. Martin and W. Martin (2015) succinctly note, library instruction games are not exempt from the old adage "fast, cheap, and good: pick any two" (p. 644). Additionally, some games will have accessibility challenges. Any digital game relies on the assumption that players have the technology to run the game and are familiar enough with said technology to play comfortably, and that may not always be a valid assumption, especially in less affluent areas. Beyond that, the tools used to create some games (notably early versions of Adobe Flash Player) predate ARIA (Accessible Rich Internet Applications) standards and so may be difficult for players with disabilities to enjoy (Martin \& Martin, 2015, p. 653). Lastly, gamebased learning itself may not prove effective for all students. Each individual is different, and for some people, competitive elements decrease motivation rather than increase it, particularly if they start the game off poorly and feel rapidly defeated (Van Roy \& Zaman, 2018, p. 294). However, on the whole, the potential benefits outweigh the potential problems, especially since careful design can help mitigate some of these issues.

\section{Applications of Games in Academic Libraries}

Incorporating games into the information literacy instruction offerings at an academic library is not a new concept; in fact, the first documented use of a digital game in this capacity dates back to 1982 and the simple but theninnovative game Citation (Robertson \& Jones, 2009, p. 261). Simple games, like Wordle for keyword generation skills and Jeopardy for general knowledge quizzing, are the most frequently incorporated because they can be presented as mini-activities within one-shot instruction sessions. As long as a librarian has access to a computer with projection capabilities and the internet, these types of games are quick and inexpensive to put together, and both the students and the instructors can quickly understand the rules and gameplay so it doesn't unduly bog down the rest of the session (Porter, 2012, pp. 71-73).

Some libraries have taken this concept further and developed longer, more immersive games to push library instruction. Scavenger hunts, for example, are a popular introductory gaming activity often used to acquaint new incoming students with the library and its resources. While this could be a one-time game during orientation proceedings, librarians at Carthage College in Wisconsin partnered with their Student Affairs department to create a semester-long scavenging game called Get A Clue, which was loosely based on long-term gameshows like The Amazing Race (Margino, 2013, p. 336). Students formed teams and accrued points by completing voluntary tasks that rotated out each week for an entire fall semester. Get A Clue was largely successful, especially 
among first-year students. University of Florida librarians have created libraryspecific missions to be included in Humans Vs. Zombies, an enormously popular game played on college campuses nationwide (Johnson, Buhler, \& Hillman, 2010). These missions featured tasks to be completed much like a scavenger hunt, but some of them were more involved in that students were required to actually create accounts with citation aggregators and the library's e-reserves platform, among other things.

Academic libraries have also been experimenting with digital or virtual games (closer to what might be considered a typical video game) in recent years. Several more casual games built around Adobe Flash Player have been developed, including Lycoming College's Goblin Threat, which focuses on avoiding plagiarism and understanding copyright, and the Carnegie Mellon Libraries' Within Range, which teaches players how to use the Library of Congress call number system (Margino, 2013, p. 338). Some university libraries have successfully mixed social media aspects into these types of games, as seen in the University of Michigan's BiblioBouts. In BiblioBouts, students submit articles that answer given prompts or questions and then vote on and comment on other students' submissions (Markey, Leeder, \& Hofer, 2011). Perhaps the most complex library instruction game of this type yet attempted is the University of Michigan's Defense of Hidgeon. This Black-Plague-themed game is essentially a virtual board game that attempts to familiarize students with the complete research process, from topic selection to beginning cursory research to in-depth database navigation and source evaluation. While the intentions were good, this particular game was too complex to be truly successful, as several students found themselves lost or confused and many were not engaged enough to continue playing without being coerced by their teachers (Markey et al., 2009).

Perhaps the most interesting and successful game-based learning attempts thus far, at least in the world of library instruction, have been alternate reality games (ARGs). ARGs use the real world as context for the game, incorporating regular communications devices (cellphones, email, etc.) as controls. The Rose Library at James Madison University developed a mystery-themed ARG as an introductory teaching tool specifically for incoming engineering students (Giles, 2015). This game, Mystery at the Library, invited students to follow a series of scavenger-hunt-like clues through existing library resources and platforms to solve a mystery. Because there was no game board, virtual gaming interface, or even launch-point website, this game was extremely budget-friendly to create; the only cost was the time of the librarians who worked on it, since each piece of the game was an already-existing library resource (Giles, 2015, p. 174). Furthermore, Giles specifically notes that "while it is possible that multimedia elements, more elaborate props, or the use of actors might have made the game more entertaining, none of the survey respondents suggested such additions" (p. 175). They were able to achieve solidly favorable results, particularly in students' knowledge of and use of RefWorks, by developing a technology-based, narrative-driven game.

\section{Project Velius and Her Story}


As documented by Battles, Glenn, and Shedd, the University of Alabama Libraries created a web-based ARG in 2010 called Project Velius. Before they begin explaining their project, they state that "the difference between Call of Duty, World of Warcraft, or any other popular commercial title and any game developed by a library or academic institution is a gulf that even generous grant funding cannot span" (Battles et al., 2011, p. 115). The point is well-taken that libraries cannot create video games at the same scale as massive production companies, but they may be closer to that mark than they realize. Her Story sold hundreds of thousands of copies to people who were interested not because they had been assigned the game as homework, but because the game was engaging on its own merits. It was created by one game developer, one actress, and one musical composer. Project Velius reached a much smaller audience, but the two games have a great deal in common.

The University of Alabama team explains that they chose to create an ARG because there are no clearly defined rules or pre-known winning conditions; instead, the player learns how to play the game as they go, discovering the rules and mechanics as they discover the underlying narrative (Battles et al., 2011, p. 118). Her Story cannot be an ARG because specific software was created for it, but nonetheless, players are only presented with the fictional police database and the first clip to begin the game. Everything else must be learned as the player progresses. The Project Velius team decided early on that strong character development would be necessary to keep players engaged, so they worked for the better part of a year to create a fully actualized Twitter account and WordPress blog for their fictitious main character (Battles et al., 2011, p. 120). Similarly, Her Story is a game fully based in the narrative and the main character. The developer, Sam Barlow, kept a blog about the game's development, in which he says, "I will go deep on story [and] explore authentic and true characters" (Barlow, 2014b, para. 2). Both games encourage the same discovery-based learning process, and both games recognize the attention-keeping power of a strong narrative and strong characters.

The most significant similarity is the educational value of both games. As previously mentioned, whether Her Story intended to teach library instruction or not, it does an excellent job of requiring players to master the art of database searching with keywords and Boolean operators, and also requires players to experience part of the research process in refining searches and discovering new avenues of investigation. The University of Alabama Libraries stated that players responding to surveys after playing the game overwhelmingly reported increased knowledge of library services as well as general enjoyment of the game (Battles et al., 2011, p. 128).

Project Velius was the University of Alabama's first attempt at creating a game to teach library instruction, and the factor that separates them the most from Her Story's success is the degree to which they tried to hide the game in real life. They chose to have the game move forward in real time, which wasn't a quick enough progression for many players, and they stopped playing after the first week or so of the semester when the game was originally scheduled to continue over eight weeks (Battles et al., 2011, p. 128). Rather than focusing so intensely 
on disguising the fact that Project Velius was a game at all, they would have been better served (as demonstrated in Her Story) to focus on hiding the educational content within the game.

\section{Conclusion}

Game-based learning is an innovative pedagogical technique that has the potential to address some of the growing disconnect between modern students and traditional teaching methods. There are several ways of gamifying educational content requiring varying degrees of financial and time investments, but most have proven to be worthwhile endeavors thus far, offering several benefits to students and instructors alike with relatively few drawbacks. Academic libraries should continue to experiment with gamification, and perhaps most importantly, publish their results. While the literature is not bereft of works on gamified pedagogy, there are relatively few published explanations or reflections on attempts to incorporate gamification within library instruction. Additional examples and case studies would help the profession as a whole through the trialand-error portion of working with new pedagogical methods.

Of the currently available published case studies, the gamified learning attempts are mostly smaller, more contained efforts requiring relatively little investment. There are commercially successful examples available (like $\mathrm{Her}$ Story) from which to draw inspiration and guidance, and libraries should not feel intimidated by their newness in the arena of gaming. Larger-scale gaming projects may require more investment upfront, but they can be recycled for many years and may yield significantly better results in terms of user engagement with the material and retention. In short, they are worth the risk. Project Velius was very similar to Her Story in many ways, and that was a first-attempt game created back in 2010. Imagine what kinds of games academic libraries might be capable of creating almost a decade later. 


\section{References}

Barlow, S. (2014a). Her Story: What is it? Retrieved from http://www.herstorygame.com/about/

Barlow, S. (2014b). Her Story Blog: Design pillars. Retrieved from http://www.herstorygame.com/design-pillars/

Barlow, S. (2015). Her Story [Video game]. Microsoft Windows: Sam Barlow.

Battles, J., Glenn, V., \& Shedd, L. (2011). Rethinking the library game: Creating an alternate reality with social media. Journal of Web Librarianship, 5, 114-131. Retrieved from https://www.tandfonline.com/doi/abs/10.1080/19322909.2011.569922

Buckley, P., Doyle, E., \& Doyle, S. (2016). Game on! Students' perceptions of gamified learning. Educational Technology and Society, 20(3), 1-10. Retrieved from https://eric.ed.gov/?id=EJ1146979

Gee, J.P. (2007). What video games have to teach us about learning and literacy. New York: Palgrave Macmillan.

Giles, K. (2015). No budget, no experience, no problem: Creating a library orientation game for freshman engineering majors. The Journal of Academic Librarianship, 41, 170-177. Retrieved from https://www.sciencedirect.com/science/article/abs/pii/S009913331400268 7

Johnson, M., Buhler, A. G., \& Hillman, C. (2010). The library is undead: information seeking during the zombie apocalypse. Journal of Library Innovation, 1(2), 29-43.

Kaneko, K., Saito, Y., Nohara, Y., Kudo, E., \& Yamada, M. (2018). Does physical activity enhance learning performance?: Learning effectiveness of game-based experiential learning for university library instruction. The Journal of Academic Librarianship, 44, 569-581. Retrieved from https://www.sciencedirect.com/science/article/abs/pii/S009913331730452 4

Kaufmann, D. A. (2018). Reflection: Benefits of gamification in online higher education. Journal of Instructional Research, 7, 125-132. Retrieved from https://eric.ed.gov/?id=EJ1188367

Kaya, T. (2010). A 'stealth assessment' turns to video games to measure thinking skills. The Chronicle of Higher Education. Retrieved from https://www.chronicle.com/article/A-Stealth-Assessment-Turns/125276 
Margino, M. (2013). Future voices in public services - Revitalizing traditional information literacy instruction: Exploring games in academic libraries. Public Services Quarterly, 9, 333-341. Retrieved from https://eric.ed.gov/?id=EJ1022212

Markey, K., Leeder, C., \& Hofer, A. (2011). BiblioBouts: What's in the game? College \& Research Libraries News, 72(11), 632-645. Retrieved from https://crln.acrl.org/index.php/crlnews/article/view/8668/9124

Martin, L. \& Martin, W. (2015). Modifying an information literacy game for outreach events. Reference Services Review, 43(4), 643-655. Retrieved from https://doi.org/10.1108/RSR-02-2015-0009

McAdoo, M. L. (2012). Fundamentals of library instruction. E-book: American Library Association.

Omeluzor, S.U., Akibu, A. A., Dika, S. I., \& Ukangwa, C. C. (2017). Methods, effects, and challenges of library instruction in academic libraries. Library Philosophy and Practice, 1-26. Retrieved from https://digitalcommons.unl.edu/libphilprac/1465/

Porter, T. D. (2012). Games and activities: An alternative foundation for library instructional learning. Codex: The Journal of the Louisiana Chapter of the $A C R L, 2(2), 61-77$. Retrieved from http://journal.acrlla.org/index.php/codex/article/view/72

Robertson, M. J., \& Jones, J. G. (2009). Exploring academic library users' preferences of delivery methods for library instruction: Webpage, digital game, and other modalities. Reference \& User Services Quarterly, 48(3), 259-269. Retrieved from https://journals.ala.org/index.php/rusq/article/view/3380

Smale, M. A. (2011). Learning through quests and contests: Games in information literacy instruction. Journal of Library Innovation, 2(2), 36-55. Retrieved from https://pdfs.semanticscholar.org/d312/28d1533b166509df3fc2cc9bf6d498f $5 \mathrm{cf} 32 . \mathrm{pdf}$

Van Roy, R. \& Zaman, B. (2018). Need-supporting gamification in education: An assessment of motivational effects over time. Computers \& Education, 127, 283-297. Retrieved from https://doi.org/10.1016/j.compedu.2018.08.018

Zhang, B., Robb, N., Eyerman, J., \& Goodman, L. (2017). Virtual worlds and gamification to increase integration of international students in higher education: An inclusive design approach. International Journal of $E$ - 
School of Information Student Research Journal, Vol. 9, Iss. 2 [2019], Art. 6

Learning and Distance Education, 32(2), 1-21. Retrieved from https://eric.ed.gov/?id=EJ1164422 